\title{
Cranioplasty using Polymethylmethacrylate (PMMA) self-curing by the conventional casting process: clinical case report
}

\author{
Cranioplastia com uso do Polimetilmetacrilato (PMMA) autopolimerizável pelo processo de moldagem \\ convencional: relato de caso clínico
}

Jamil Elias DIB ${ }^{1}$
(D) ORCID iD 0000-0002-5306-4783
Mario Serra FERREIRA ${ }^{2}$
(i) ORCID iD 0000-0001-5691-6550
Matheus Branco Elias DIB ${ }^{3}$
(i) ORCID iD 0000-0002-8982-7519
Wolney Ronaldo Abrahão SILVA ${ }^{4}$
(i) ORCID iD 0000-0001-5382-4255
Ricardo Guimarães NEVES
(D) ORCID iD 0000-0003-0415-2645
Érica Miranda de TORRES 5
(D) ORCID iD 0000-0002-5544-6865
João Batista de SOUZA ${ }^{5}$

(iD) ORCID iD 0000-0002-7476-9950

\begin{abstract}
Cranioencephalic trauma which results in extensive edema and / or bruising usually requires surgical treatment through a greater withdrawal of the bone portion. Thus, the absence of bone tissue implies the lack of protection of the brain tissue or even compromises the esthetics especially when located in the frontal or frontoparietal region. The purpose of this case report is to describe a treatment option for head trauma, through the prefabricated part by obtaining the skull model. These bone faults can be reconstructed either by the direct method using polymethylmethacrylate directly on the defects or by means of pre-made pieces such as prototyping or from the skull model. Although other techniques have many good points, some show certain drawbacks, from storage conditions below abdominal fat, preheating due to the release of heat during the high polymerization reaction or the high cost when they are prototyped. The technique described in this work reports its simple performance, eliminating the risk of local heating, allows prior sterilization in autoclave, it is biocompatible, allows perfect anatomical recovery, easy placement, low cost, also highlighs the advantage of the bucomaxillofacial surgeon's performance due to the familiarization with the relevant head and neck procedures. Clinical and tomographic examination after 24 months of treatment showed stability of the polymethylmethacrylate plate, adhesions to the bone margins, and absence of tissue alterations.
\end{abstract}

Indexing terms: Craniectomy. Polymethylmethacrylate. Prosthetics.

\section{RESUMO}

Os traumatismos cranioencefálicos que resultam em extensos edemas e ou hematomas normalmente, requerem tratamentos cirúrgicos por meio de uma retirada maior de porção óssea. Deste modo, a ausência do tecido ósseo implica na falta de proteção do tecido cerebral ou até mesmo comprometer a estética especialmente, quando localizadas na região frontal ou frontoparietal. O objetivo deste relato de caso é descrever uma opcão de tratamento para os traumatismos cranioencefálicos, por meio da peça pré-fabricada mediante a obtenção do modelo do crânio. Estas falhas ósseas podem ser reconstruídas tanto pelo método direto utilizando o polimetilmetacrilato diretamente sobre as falhas ou por meio das peças pré-confeccionadas como a prototipagem ou a partir do modelo do crânio. Embora outras técnicas apresentem muitos pontos positivos, algumas mostram determinados inconvenientes, desde condição de armazenamento abaixo da gordura abdominal, aquecimento prévio devido a liberação de calor durante a reação de alto polimerização ou o alto custo quando são prototipadas. A técnica neste trabalho descrita relata sua facilidade de execução, elimina o risco do aquecimento local, permite a prévia esterilização em autoclave, é biocompatível, permite a perfeita recuperação anatômica, fácil colocação, baixo custo, ressaltando ainda a vantagem da atuação do cirurgião bucomaxilofacial devido sua familiarização com os procedimentos pertinentes a cabeça e pescoço. Em exame clínico e tomográfico após 24 meses do tratamento, observa-se estabilidade da placa de polimetilmetacrilato, aderências às margens ósseas, e ausência de alterações tissulares.

Termos de indexação: Craniectomia. Polimetilmetacrilato. Próteses.

${ }^{1}$ Hospital Estadual de Urgências de Anápolis Dr. Henrique Santillo. Anápolis, GO, Brasil.

${ }^{2}$ Centro Universitário de Anápolis Uni Evangélica, Curso de Odontologia. Anápolis, GO, Brasil.

${ }^{3}$ Hospital Regional de Ferraz de Vasconcelos Dr. Osiris Florindo Coelho de São Paulo. São Paulo, SP, Brasil.

${ }^{4}$ Hospital de Urgências de Anápolis. Anápolis, GO, Brasil.

${ }^{5}$ Universidade Federal de Goiás, Programa de Pós-Graduação em Odontologia. Goiânia, GO, Brasil. Correspondência para / Correspondence to: RG NEVES. E-mail: <ricardogneves@hotmail.com>.

$\boldsymbol{\nabla} \nabla \boldsymbol{\nabla}$

Como citar este artigo / How to cite this article

Dib JE, Ferreira MS, Dib BEM, Silva WRA, Neves RG, Torres EM, et al. Cranioplasty using polymethylmethacrylate (PMMA) self-curing by the conventional casting process: clinical case report. RGO, Rev Gaúch Odontol. 2018;66(3):267-273. http://dx.doi.org/10.1590/1981-8637201800030000123376 


\section{INTRODUCTION}

In craniofacial trauma, even after resolution with favorable prognosis, either with sequelae or not, cranioplasty is an almost inevitable resource used for the correction of bone defects, since in many situations it is not possible to preserve bone structure during the surgical procedures [1-5].

The skull bone can be removed by craniectomy, and in some cases, such as cranial decompression, when it is removed in a larger fragment, it may be placed underneath the abdominal fat and replaced in a second time. However in many cases, this bone may undergo a reabsorption process mainly, with the increase of the time in which it is conditioned. In other cases, the bone is removed in small fragments or presented as comminuted fractures. In these latter situations, repair of the defect can be done through the cranioplasty, which can also be used to correct numerous bone deformities, both of the skull and face [6-7].

Cranioplasty is a technique whose objective is to repair as skull deformity, which may be of primary origin (congenital) or more commonly, related to trauma resulting from various types of accidents involving drivers, motorcyclists, fire guns and accidents involving interpersonal aggressions, which can cause, besides injuries to the brain, other sequelae in the lack of protection in the skull cap and aesthetics due to bone loss $[3,8]$.

Classified as secondary or acquired, this deformity may be corrected through the surgical technique in order to promote repair and may be performed by prosthesis implanting on the site of the damaged or removed part and is usually performed after a cerebral decompression [9-10].

Cranioplasty is a widely practiced neurosurgical procedure that not only aims to protect the underlying brain tissue from defects of the skull, but also seeks to restore the calvaria as well as a cosmetically acceptable contour $[1,5,11$ 12].

Some types of materials and techniques have been described for reconstruction of the calvaria, the most common of which are autogenous bone, titanium mesh, PMMA, porous polyethylene, calcium phosphate cement [3,13-15].

The autogenous bone is considered the first treatment choice, but its use is limited in the case of extensive defects, in the great morbidity of the donor site, in the unavailability, in the hardships brought by very old age and by the loss of its physical properties and reabsorption of the graft, in addition to complications such as loss of its physical structure and the need of another approach in the donor site $[9,16]$.

Due to the non-completeness of these structures, an alternative to the rehabilitation treatment is the use of a synthetic material [17], which is biocompatible, non-heat conductive, presents low thermal conductivity, radiolucent, non-magnetic, light, rigid, simple to prepare and is easy to apply and affordable, as well [18-19]. In the 1940s, PMMA acrylic polymers were used for the first time in the manufacture of cranial prostheses with promising results [20]. This product is presented in powder and liquid forms. The powder consists of prepolymerized PMMA beads and a small amount of benzoyl peroxide, the initiator. The liquid is predominantly unmixed methylmethacrylate with small amounts of hydroquinone, an inhibitor. The resins are presented under two types: chemically activated acrylic resin (RAAQ), also known as cold polymerization resin or self-curing polymerization, has its chemically activated polymerization reaction, although it has a poorly efficient type of polymerization its popularity in Dentistry is justified due to its very practical and simple to use [21].

Both neuro and bucomaxillofacial surgeries describe innumerable procedures for the treatment of cranial deformities that involve bone loss among them, nickel titanium custom prostheses, PMMA prototypes, and those made by placing PMMA directly, self-cured under the affected area, or performed by conventional methods of molding, pressing and baking the acrylic resin, or selfcuring resin on previously obtained models by means of the moldings of the skull and / or face [18]. This work aims to describe the cranioplasty method using the self-curing PMMA acrylic resin by obtaining the model in gypsum stone to correct some defects on facial bone structures as frontal and zygomatic bone.

\section{CASE REPORT}

A33year-old patient, leukoderma, non-smoker, nonalcoholic, non-illicit drug user, victim of motorcycle accident, presented traumatic brain injury with extradural hematoma formation in the left temporal region. The patient underwent 3D computed tomography (CT) imaging with reconstruction, which confirmed the presence of the hematoma. Craniectomy was then indicated for the treatment and drainage of the hematoma, which occurred within the normal range and the patient remained for a period of 15 days under intensive care. During the procedures for craniectomy, a bone window was made, but the comminuted fractures of the temporal bone did not allow its storage below the abdominal fat 
for later reconstruction, leaving the brain without local bone protection. Three months after neurological surgery, the patient was reexamined and cranial reconstruction, or cranioplasty, was planned. Given the available methods, it was possible to perform direct cranioplasty with the use of methylmethacrylate, cranioplasty by means of prototyping, the placement of the screen in titanium, and indirect cranioplasty by preforming the piece in self-polymerizing methylmethacrylate, made from model of plaster.

When analyzing the advantages and disadvantages, the indirect technique was performed using self-curing PMMA since it presents practible requirements, such as: simple to perform, physiologically non-aggressive to the brain tissue, it is biocompatible and it allows the previous sterilization in autoclave, easy adaptation and fixation and and also fulfills the anatomical, esthetic and functional requirements.

In the preoperative phase, considering the CT examinations, the extent of the bone defect in threedimensional 3D form was observed. Then the tricotomy of the scalp was performed and the borders of the bone defect
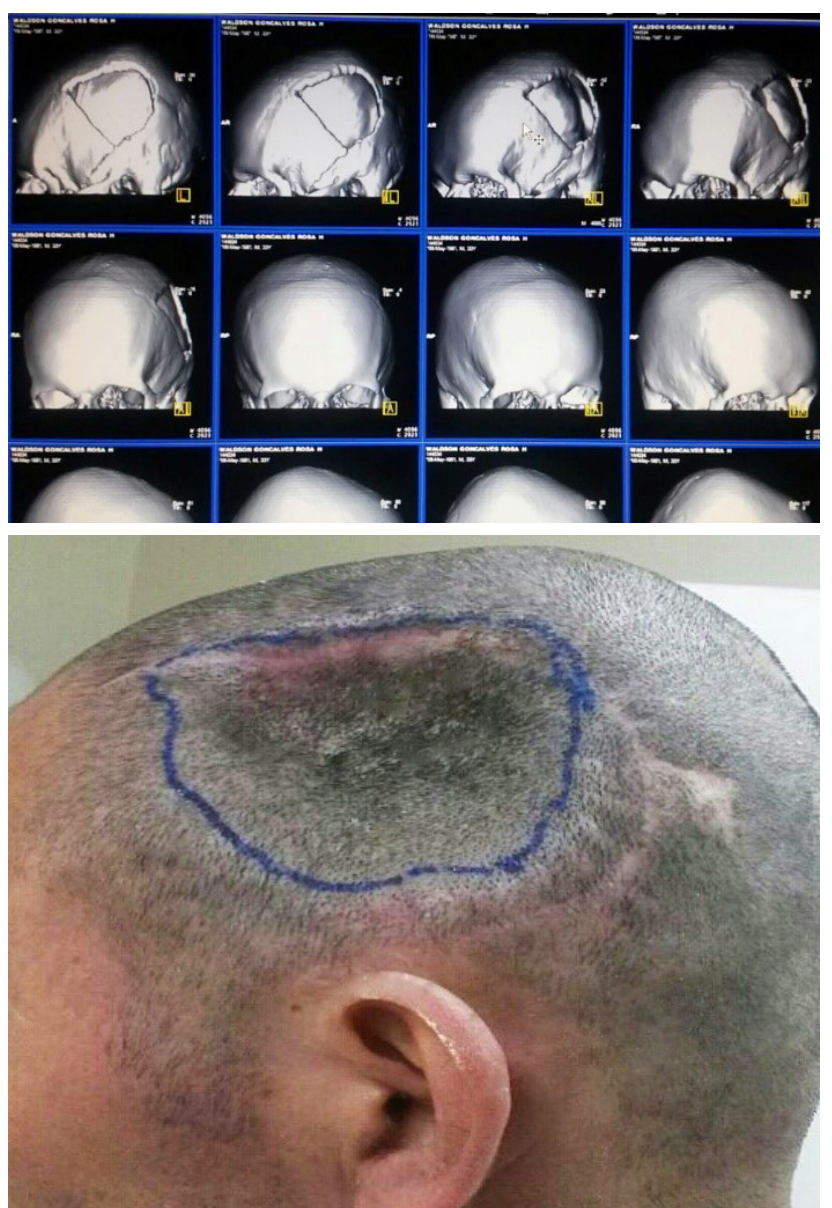

Figure 1. Computed tomography $3 \mathrm{D}$, highlithing the limits of bone failure, and extrusion. were marked with blue dye (figure 1 A-B).

The next step was the molding of the skull covering the left, right, frontal and occipital faces to obtain the symmetric reference, using the alginic acid salt (alginate) manipulated in a softer consistency in order to completely fill the region of the bone defect. After covering the entire surface with alginate, before the prey reaction started, a layer of open gasses was added to allow subsequent adhesion to Paris cast layer, for future molding (figure 2A).

After the gypsum prey reaction, the set was removed, thus obtaining, with the internal markings of the limits of the bone loss. Then a layer of gypsum stone was added to coat the inner face of the molding, with approximately $5 \mathrm{~mm}$ thickness and thus allow the strength of the model (Figure 2B).

After obtaining the model, the internal insulation was made with liquid vaseline and then, after manipulation of the colorless acrylic, it was inserted into the cavity included in the model. During the polymerization, the piece was gradually sculpted using spatulas. After the polymerization reaction, the patient's skull model was tested (figure $2 \mathrm{C}$ ).
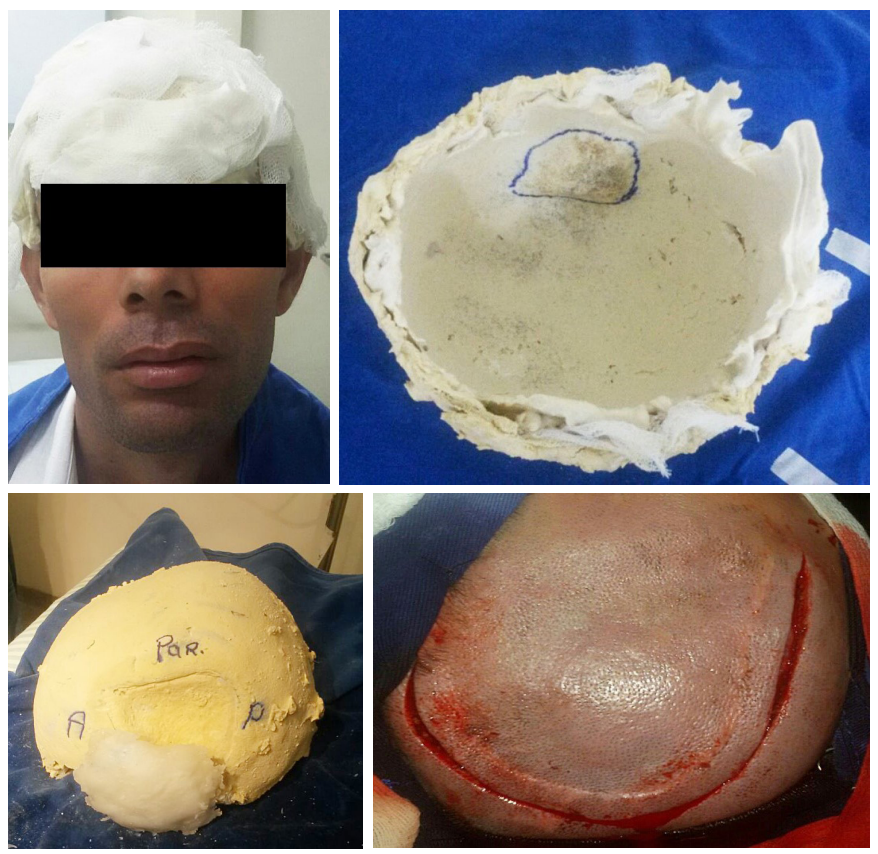

Figure 2. Physical intraoral exam, presenting increase in volume of the tongue on the left side.

Next, the final finish was done using scrubbing and polishing drills. The piece was packed in surgical grade paper and autoclaved at $121^{\circ} \mathrm{C}$ for 15 minutes in order to ensure the death of all bacterial life forms, including that of bacterial endospores which are more resistant to heat than the vegetative cells. 
In order to adapt the prosthesis, the patient was submitted to the new surgical stage under general inhalation and intravenous anesthesia. In order to access the bone defect, an incision was made at the level of the anterior one, the scalp and pericranial detachment being made, since it was fully adhered to the dura mater (figure $3 \mathrm{~A}$ e B).

After identifying the edges of the bone defect, and certifying the integrity of the dura mater, the model was adapted to remove small bone interferences. The prosthesis was fixed by three titanium plates in $\mathrm{Y}$, with four holes and 2.0 system and fixed by cortical screws and six millimeters in length. Surgical wound closure was done by simple stitch sutures using nylon 3.0 threads (figure 3 C e D).
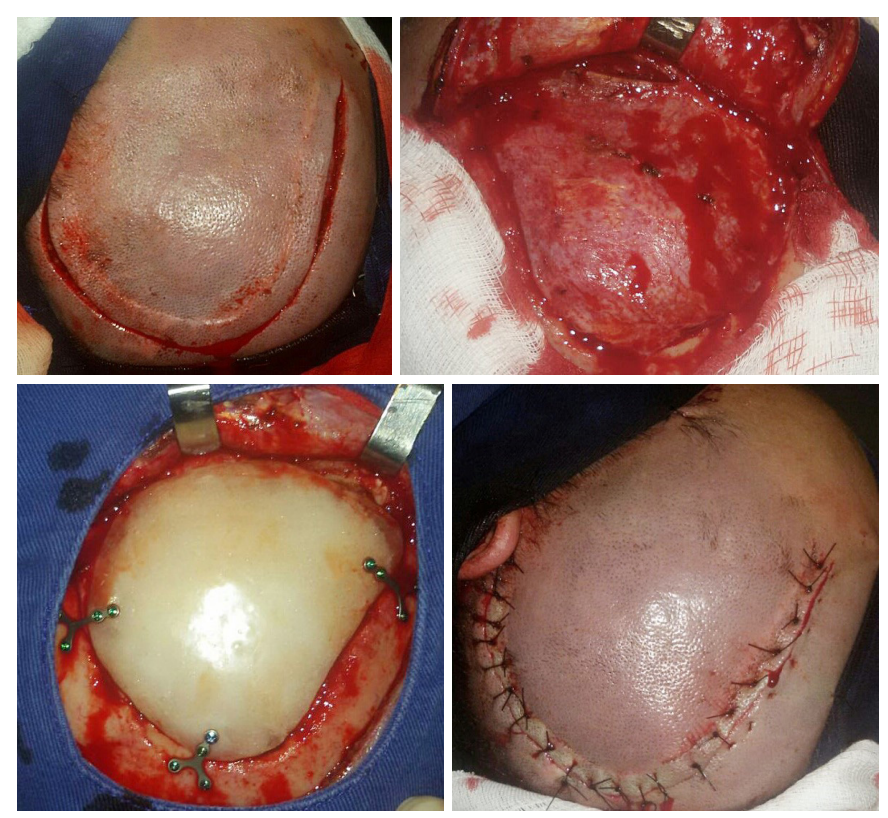

Figure 3. A - incision performed by Neurologist; B - derailment and exposure of the dura mater; $C$ - adaptation and fixation of the plate by means of three titanium plates, in $\mathrm{Y}$, with four holes and system 2.0 and fixed by cortical screws and six millimeters in length; D - simple stitches suture.

Routine procedures for elective surgeries such as prophylactic antimicrobial ( $2 \mathrm{~g}$ of cefazolin via EV for a 48hour period, analgesics (dipyrone $2 \mathrm{~mL}$ via $\mathrm{EV}$, if necessary) anti-inflammatory (tenoxican $20 \mathrm{mg} \mathrm{EV}$ at $12 \times 12$ hour intervals), antiemetic (bromopride, $2 \mathrm{ml}$ EV every $12 \mathrm{~h}$ ) and gastric protector (ranitidine at $50 \mathrm{mg}$ EV every 6 hours or if necessary).

The immediate postoperative concluded that there was good adaptation, ample protection of the cerebral structure and the restoration of esthetics (figure 4).

After the twenty-four months follow-up by CT (figure 5) there was perfect adaptation, maintaining the esthetic profile and bone adaptation.

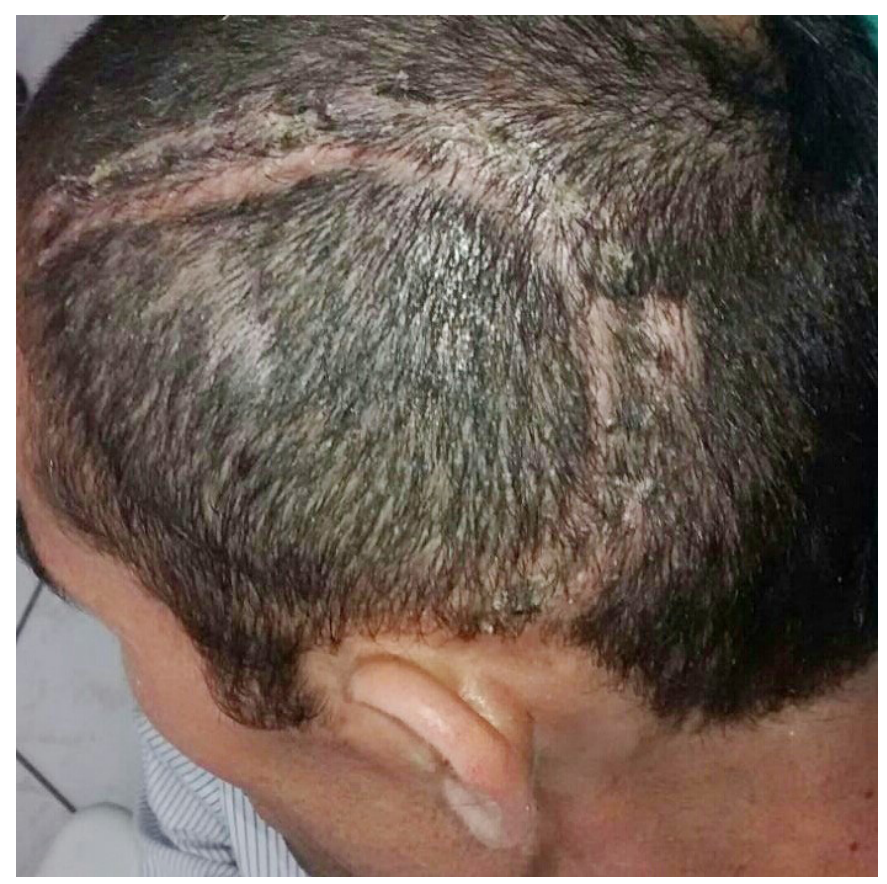

Figure 4. Postoperative aspect 15 days after removal of the stitches, with return of the aesthetics and function.

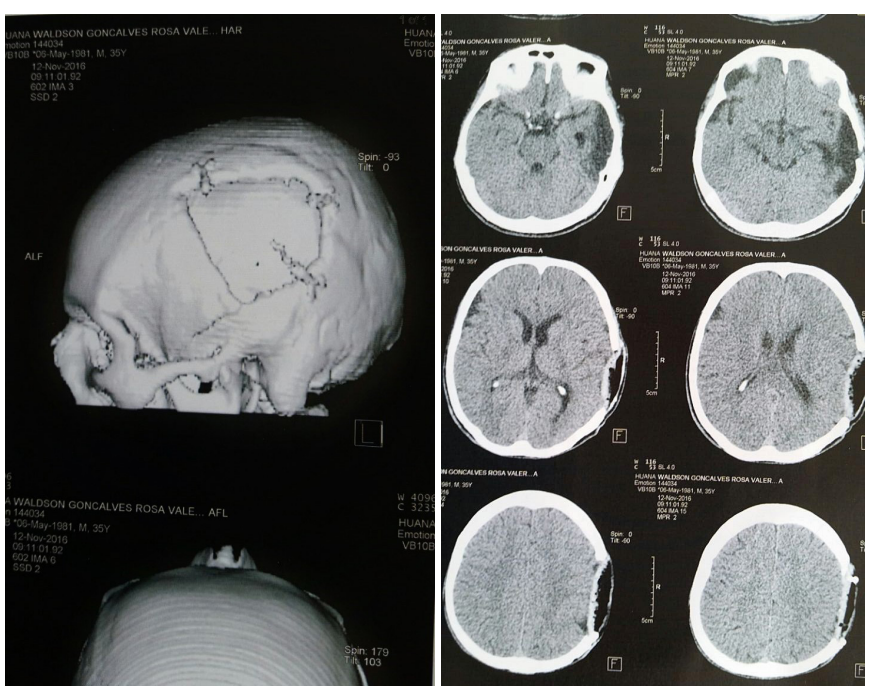

Figure 5. Computed tomography after 24-month follow-up, adaptation with bone edges and the presevated boundary between the prosthetic part and the dura mater.

\section{DISCUSSION}

Cranioplasty is a relatively simple procedure, but post-operative problems such as infection, bone resorption may arise, and when the bone that has been stored is used hematomas may appear [17]. In the case studied, after control under CT scan, integrity was observed between the prosthesis and the surrounding bone structure, without any complications. 
The most commonly used alloplastic materials for customization include bioceramics, titanium mesh and PMMA, and there is no consensus, in the current literature, regarding the most appropriate material for use in this type of reconstruction $[13,22]$. Regarding material rejection and infections, when compared to the bone graft, they have the advantage of not being reabsorbed, and the chances of infection and implant loss are less significant $[13,22]$. These advantages were evidenced in the case described here.

Various materials have been proposed to reconstitute the deformities caused by craniofacial trauma including autogenous bone and different types of synthetic resins and, finally, the titanium alloys or even by the pieces constructed by prototyping both titanium and acrylic [3$4,12,16]$.

PMMA is one of the inert materials that has a better representation due to its low thermal and magnetic conductivity, it is biocompatible, inert, resistant to infections, light, radiolucent, readily available, low cost, and characterized as the main advantage the possibility of pre - making the prosthesis preoperatively $[1,5,19-20]$ which was possible due to the dentist's experience in face of the procedures of molding as well as use of dental materials.

The polymerization process is initiated by the reaction between benzoyl peroxide and strongly exothermic N-dimethyl-p-toluidine, and the PMMA material may exceed the temperature of $8000 \mathrm{C}$ however by the direct technique this can be controlled by means of irrigations with saline solutions at room temperature. The direct method may still cause the deformation of the part since it is constantly removed from the place in order to control its heat released. In the technique described in this manuscript, this inconvenience was avoided since the piece had been previously pre-made. PMMA is normally well tolerated and allows the formation of bone on its surface (Osteoconductor). After polymerization, usually over time, the toxicity should disappear completely within four hours [18,21]. Regarding exothermia and its action on tissues, although the authors state that it is not harmful, the preparation of a prefabricated piece, as in the clinical case presented here, was to avoid or minimize a possible aggression factor, corroborating with the literature that the material has a good tolerance in relation to the tissues and that, with the process of Off-site self-cushioning reaction, this also minimizes toxicity. Over time PMMA has been shown to be compatible without presenting biological side effects as a foreign body $[1,22]$. This statement can be confirmed in this case report, since there are no signs or symptoms of adverse reactions, and during this time of follow-up as shown by CT exams.

Huang et al. [9]. have reported that since 1940, PMMA has been a widely used material for secondary cranial reconstruction, although other implant design processes have evolved from a conventional casting technique to a designed computer complex; a process capable of producing a variety of forms. In the case reported, for socioeconomic reasons, the manual procedures were used according to the principles of conventional molding used in Dentistry until the preparation of the prosthesis.

PMMA is the most used material, presenting medium strength produces acceptable tissue reactions, able to adhere tightly to the bone, is not a conducting term, it is easy to obtain and low cost [10]. Up to the present moment in which the procedure was followed, twentyfour months, according to the computerized tomography image, no tissue changes were observed, which reinforces the hypothesis of biocompatibility and adhesions to the bone margins, being in agreement with the above author mentioned.

The use of PMMA, as a filling and repair material for tissues, presents some disadvantages such as allergies and formation of granulomas, as well as superficial projections forming visible nodules. Despite the advantages, it is well known that acrylic bone cements may cause bone or soft tissue necrosis due to the properties of its components and polymerization [6,23-24]. To date, these inconveniences have not been observed, contrary to some reports in the literature.

According Marchac \& Greensmith [11], PMMA can be used directly during the surgical area, applying it on the bone defect while the material is in the plastic phase of polymerization. When the material initiates polymerization, an exothermic reaction occurs and the generation of heat must be controlled by irrigation with cold saline solution.

The technique described in this case report allows the prosthesis to be made using both self-polymerizable and polymerizable resins by pressing and heating muffle. According to the socioeconomic reality, these two techniques, although little used to the detriment of the technological innovations, are more accessible while facing social reality. In addition, it can be stated that the material presents complete polymerization, shortening of the surgical procedure time, and assuring physical properties such as compression, impact and shear strength, as described in the literature. 


\section{CONCLUSION}

During the twenty-four months of proservation, it was verified that there were no signs of rejection and that through $\mathrm{CT}$ control it was possible to verify the perfect adaptation with the bony edges as well as the preseved limit between the prosthetic part and the dura mater. The choice of PMMA was due to its physical and biological property as resistance, biocompatibility, easy manipulation and low cost. The esthetic benefits and protection of the brain were also achieved, so that the patient returned to work, has social interaction and is currently under regular follow-up.

\section{REFERENCES}

1. Chiarini L, Figurelli S, Pollastri G, Torcia E, Ferrari F, AlbaneseM, et al. Cranioplasty using acrylic material: a new technicalprocedure. J Craniomaxillofac Surg. 2004;32(1):5-9. doi: 10.1016/j.jcms.2003.08.005.

2. Brasileiro BF, Passeri, LA. Epidemiological analysis of maxillofacial fractures in Brazil: a 5-year prospective study. Oral Surg Oral Med Oral Pathol Oral Radiol Endod. 2006;102(1):28-34. doi: 10.1016/j.tripleo.2005.07.023

3. Sahoo N, Roy ID, Desai AP, Gupta V. Comparative evaluation of autogenous calvarial bone graft and alloplastic materials for secondary reconstruction of cranial defects. J Craniofac Surg. 2010;21(1):79-82. doi: 10.1097/SCS.0b013e3181c3ba58

4. Ruy CCAF, Thais MOO, Natalino LN, Carla G, Ruy CCA. Reconstruction of bony facial contourdeficiencies with polymethylmethacrylate implants: case report. J Appl Oral Sci. 2011;19(4):426-30. doi: 10.1590/S1678-77572011000400021

5. Al-Tamimi $Y Z$, Sinha P, Trivedi M, Robson C, Al-Musawi TA, Hossain $\mathrm{N}$, et al. Comparison of acrylic and titanium cranioplasty. $\mathrm{Br} J$ Neurosurg. 2012;26(4):510-3. doi: 10.3109/02688697.2011.633640

6. Cheng YK, Weng HH, Yang JT, Lee MH, Wang TC, Chang CN. Factors affecting graft infection after cranioplasty. J Clin Neurosci. 2008; 15(10):1115-9. doi: 10.1016/j. jocn.2007.09.022.

7. Inamasu J, Kuramae T, Nakatsukasa M. Does difference in the storage method of bone flaps after decompressive craniectomy affect the incidence of surgical site infection after cranioplasty? Comparison between subcutaneous pocket and cryopreservation. J Trauma. 2010;68(1):183-7. doi: 10.1097/ TA.0b013e3181c45384

8. Song T, Qiu ZY, Cui FZ. Biomaterials for reconstruction of cranial defects. Front Mat Sci. 2015;9(4):346-354. doi: 10.1055/s0036-1592411

9. Huang GJ, Zhong S, Susarla SM, Swanson EW, Huang J, Gordon CR. Craniofacial reconstruction with poly(methyl methacrylate) customized cranial implants. J Craniofac Surg. 2015 Jan;26(1):64-70. doi: 10.1097/SCS.0000000000001315
Collaborators

JB SOUZA and ÉM TORRES, advised, designed, revised the theoretical assumptions and wrote the paper and documentation, preparation of figures. JE DIB, MS FERREIRA, MBE DIB and NEVES RG were responsible for performing the surgery and monitoring the hospitalized patient follow-up during the clinic case, checking record, collecting systemic data and for writing this paper. WRA SILVA was responsible for part of the surgery and he also took part in the discussion and in the writing process of this paper.

10. Fiaschi P, Pavanello M, Imperato A, Dallolio V, Accogli A, Capra V, et al. Surgical results of cranioplasty with a polymethylmethacrylate customized cranial implant in pediatric patients: a single-center experience. J Neurosurg Pediatr. 2016 Jun;17(6):705-10. doi: 10.3171/2015.10.PEDS15489

11. Marchac D, Greensmith A. Long-term experience with methylmethacrylate cranioplasty in craniofacial surgery. J Plast Reconstr Aesthet Surg. 2008;61(7):744-52. doi: 10.1016/j. bjps.2007.10.055

12. Seckin A, Baris K, Bashar A, Sabri A, Galip Z. Cranioplasty: review of materials and techniques. J Neurosci Rural Pract. 2011;2(2):1627. doi: 10.4103/0976-3147.83584

13. Lee $\mathrm{El}$, Chao AH, Skoracki RJ, Yu P, DeMonte F, Hanasono MM. Outcomes of calvarial reconstruction in cancer patients. Plast Reconstr Surg. 2014;133(3):675-82. doi: 10.1097/01. prs.0000438061.46290.33

14. Chang V, Hartzfeld $P$, Langlois $M$, Mahmood A, Seyfried D. Outcomes of cranial repair after craniectomy. J Neurosurg. 2010 May;112(5):1120-4. doi: 10.3171/2009.6.JNS09133

15. Gilardino MS, Karunanayake M, Al-Humsi T, Izadpanah A, Al-Ajmi $\mathrm{H}$, Marcoux J, et al. A comparison and cost analysis of cranioplasty techniques: autologous bone versus custom computer-generated implants. J Craniofac Surg. 2015;26(1):113-7. doi: 10.1097/ SCS.0000000000001305

16. Chim H, Gosain AK. Biomaterials in craniofacial surgery: experimental studies and clinical application. J Craniofac Surg. 2009 Jan;20(1):29-33. doi: 10.1097/SCS.0b013e318190dd9e

17. Bobinski L, Koskinen LO, Lindvall P. Complications following cranioplasty using autologous bone or polymethylmethacrylate-retrospective experience from a single center. Clin Neurol Neurosurg. 2013 Sep;115(9):1788-91. doi: 10.1016/j. clineuro.2013.04.013

18. Abdo F, Oliveira MT, Neto LN, Gurgel C, Abdo CCR. Reconstruction of bony facial contourdeficiencies with polymethylmethacrylate implants: case report. J Appl Oral Sci. 2010;19(4):426-30. doi: 10.1590/S1678-77572011000400021

19. Sorour M, Caton WL, Couldwell WT. Technique for methyl methacrylate cranioplasty to optimize cosmetic outcome. Acta Neurochir (Wien). 2014;156(1):207-9. doi: 10.1007/s00701-013$1800-3$ 
20. Sanan A, Haines SJ. Repairing holes in the head: a history of cranioplasty. Neurosurgery. 1997;40(3):588-603. doi: 10.1097/0006123-199703000-00033

21. Govila, A. Use of methyl methacrylate in bone reconstruction. $\mathrm{Br} J$ Plastic Surg. 1990;43(2):210-6. doi: 10.1016/00071226(90)90163-T

22. Chen TM, Wang HJ, Chen SL, Lin FH. Reconstruction of posttraumaticrontal-bone depression using hydroxyapatite cement. Ann Plast Surg. 2004;52(3):303-8.

23. Haneke E. Polymethyl metacrilate microspheres in collagen. Semin Cutan Med Surg Med Surg. 2004;23(4):227-32. doi: 10.1016/j.sder.2004.08.002
24. Cakarer S, Selvi F, Isler SC, Olgac V, Keskin C. Complication of Polymethylmethacrylate Bone Cement in the Mandible. J Craniofac Surg. 2010;21(4):1196-8. doi: 10.1097/SCS

Received on: 10/11/2017

Final version resubmitted on: 22/3/2018

Approved on: 23/5/2018 